\title{
Non-Native Species and Biodiversity Assessment
}

\section{Giulia Guerriero*}

Federico II University, Naples, Italy

Climate change and direct effect of human activities imply the necessity to establish the biological pollution nature and magnitude; set objectives; consider the full range of alternatives; determine risk; assess benefits versus risks [1-2]. With increased human populations, and consequent demands for more resources, there will be an ever increasing number of species at risk [3-5]. Advances in sampling technology permit to survey previously unexplored areas and improve assessment of biodiversity, a fundamental step in defining the state of exploited specie and the environmental changes [6]. Several different approaches may be applied to discriminate among species, including analysis of geographic variations in morphometric and meristic characters [7], electrophoresis and isoelectric focusing [8], immunological methods [9] and, more recently, proteomic analysis [10] and DNA microarrays [11]. Generally, these techniques, especially isoelectric focusing, have been widely used and proved to be reliable and discriminative. Therefore, the application of DNA technology to species identification grew enormously during the last two decades [12]. The advent of recombinant DNA techniques generated more reliable genetic markers useful to address the problem of genetic identification of species with high sensitivity and specificity. Although both nuclear and mitochondrial DNA are theoretically available for species identification, vertebrate and invertebrate mitochondrial genes present a high mutation rate which allows the discrimination of even closely related species [13]. Nevertheless, the design of a great variety of universal primers for polymerase chain reaction (PCR) amplification of specific mitochondrial DNA (mtDNA) sequences, has promoted the use of mtDNA markers for species identification [14,15]. Most studies assume that non-native species can affect negatively native Mediterranean biota, while a few others contend that allochthonous in coastal waters seem to play a beneficial role in ecosystem functioning [16]. Any case if species at risk are relatively easy to identify, saving them is another matter. There has been an upsurge in scientific research aimed at guiding management and conservation of species at risk and/ or rational and sustainable use of water resources. They highlight the importance of understand the natural disturbance regimes, recognizing the scope, scale, and temporal patterns of change [17]. Evolutionary history or phylogeny provides one natural measure of biodiversity through the popular phylogenetic diversity (PD) measure. The evolutionary model underlying PD means that it can be interpreted as quantifying the relative feature diversity of sets of species. Quantifying feature diversity measures possible future uses and benefits or option values. Interpretation of PD as counting-up features is the basis for an emerging broad family of PD calculations, of use to both biodiversity researchers and decision makers [18]. To save species at risk, in fact, we must manage, our protected and other areas, within the framework of ecological integrity and understand that this can only be accomplished in community and regionally acceptable models. To address these aspects, our journal solicits its potential readers and authors to send their original research articles, comments, discovery notes and reviews on biological pollution studies for biodiversity conservation strategies.

\section{References}

1. Azzurro E, Moschella P, Maynou F (2011) Tracking Signals of Change in Mediterranean Fish Diversity Based on Local Ecological Knowledge. PLoS ONE 6: e24885.

2. Elliot $M$ (2003) Biological pollutants and biological pollution an increasing cause for concern. Marine Pollution Bulletin 46: 275-280.
3. Faith DP, Magallón S, Hendry AP, Conti E, Yahara T, et al (2010) Evosystem services: an evolutionary perspective on the links between biodiversity and humanwell-being. Curr. Opin. Environ. Sustain 2: 66-74.

4. Leprieur F, Brosse S, García-Berthou E, Oberdorff T, Olden JD, et al (2009) Scientific uncertainty and the assessment of risks posed by non-native freshwater fishes. Fish and Fisheries 10: 88-97.

5. Navarro E, Caputo L, Marcé R, Carol J, Benejam L, et al (2009) Ecological classification of a set of Mediterranean reservoirs applying the EU Water Framework Directive: a reasonable compromise between science and management. Lake and Reservoir Management 25: 364-376.

6. Hurford C, Schneider M, Cowx IG (2010) Conservation monitoring in freshwater habitats: a practical guide and case studies. Monitoring biological invasions in freshwater habitats. Springer, Dordrecht, Netherlands.

7. Bardamaskos G, Tsiamis K, Panayotidis P, Megalofonou Pa (2009) New records and range expansion of alien fish and macroalgae in Greek waters (south-east Ionian Sea). Marine Biodiversity Records 2:e124.

8. Berrini A, Tepedino V, Borromeo V, Secchi C (2005) Identification of freshwater fish commercially labelled "perch" by isoelectric focusing and two-dimensional electrophoresis. Food Chemistry 96:163-168.

9. Ochiai $Y$, Watabe $S(2003)$ Identification of fish species in dried fish products by immunostaining using anti-myosin light chain antiserum. Food Research International 36: 1029-1035.

10. Mazzeo MF, Giulio BD, Guerriero G, Ciarcia G, Malorni A et al (2008) Fish Authentication by MALDI-TOF Mass Spectrometry. Journal of Agricultural and Food Chemistry 56: 11071-11076.

11. Kochzius M, Nölte M, Weber H, Silkenbeumer N, Hjörleifsdottir S, et al (2008) DNA Microarrays for Identifying Fishes. Marine Biotechnology 10: 207-217.

12. Sulaiman ZH, Ovenden JR (2009) Population genetic evidence for the east-west division of the narrow-barred Spanish mackerel (Scomberomorus commerson, Perciformes: Teleostei) along Wallace's Line. Biodiversity and Conservation 19: 563-574.

13. Kyle CJ, Wilson CC (2007) Mitochondrial DNA identification of game and harvested freshwater fish species. Forensic Science International 166: 68-76.

14. Finizio AD, Guerriero G, Russo GL, Ciarcia G (2007) Identification of gadoid species (Pisces, Gadidae) by sequencing and PCR-RFLP analysis of mitochondrial $12 S$ and $16 S$ rRNA gene fragments. European Food Research and Technology 225: 337-334.

15. Smith MA, Fisher BL (2009) Invasions, DNA barcodes, and rapid biodiversity assessment using ants of Mauritius. Front Zool 6: 31.

16. Leprieur F, Brosse S, García-Berthou E, Oberdorff T, Olden JD et al (2009) Scientific uncertainty and the assessment of risks posed by non-native freshwater fishes. Fish and Fisheries 10: 88-97.

17. Campbell M (2012) Biodiversity and Endangered Species: Issues of Significance. J Biodivers Endanger Species 1:e102.

18. Faith DP (2013) Biodiversity and evolutionary history: useful extensions of the PD phylogenetic diversity assessment framework. Ann N Y Acad Sci 1289 69-89.

*Corresponding author: Giulia Guerriero, Federico II University, Naples, Italy, Tel: +390812535140; E-mail: giulia.guerriero@unina.it

Received June 21, 2013; Accepted June 22, 2013; Published June 27, 2013

Citation: Guerriero G (2013) Non-Native Species and Biodiversity Assessment. J Biodivers Endanger Species 1: e104. doi:10.4172/2332-2543.1000e104

Copyright: (c) 2013 Guerriero G. This is an open-access article distributed under the terms of the Creative Commons Attribution License, which permits unrestricted use, distribution, and reproduction in any medium, provided the original author and source are credited. 